\title{
INFLATION AND WEALTH DISTRIBUTION
}

\author{
BURKHARD HEER \\ BERND SÜSSMUTH
}

CESIFO WORKING PAPER NO. 835

CATEgory 6: Monetary Policy AND InTERnational FinANCE

JANUARY 2003
An electronic version of the paper may be downloaded
- from the SSRN website: www.SSRN.com
- from the CESifo website: www.CESifo.de




\title{
INFLATION AND WEALTH DISTRIBUTION
}

\begin{abstract}
The effect of a permanent change of inflation on the distribution of wealth is analyzed in a general equilibrium OLG model that is calibrated with regard to the characteristics of the US economy. Poor agents accumulate savings predominantly in the form of money, while rich agents participate in the stock market and accumulate equity. Surprisingly, an increase of inflation results in a lower stock market participation rate; in addition, the distribution of wealth becomes more unequal, even though the quantitative effect is economically negligible. Furthermore, we show that the welfare costs of anticipated inflation are considerably lower than in Imrohoroglu (1992).
\end{abstract}

JEL Classification: D31, E31, E44, E52.

Keywords: inflation, welfare costs, wealth distribution, stock market participation.

Burkhard Heer

University of Bamberg

Department of Economics

Feldkirchenstrasse 21

96052 Bamberg

Germany

\author{
Bernd Süssmuth \\ University of Bamberg \\ Department of Economics \\ Feldkirchenstrasse 21 \\ 96052 Bamberg \\ Germany
}

Burkhard.Heer@sowi.uni-bamberg.de 


\section{Introduction}

The literature discusses several channels through which inflation may alter income, earnings, or wealth distributions. Among others, these channels include differential indexation of wages across income groups, disproportionally allocated subsidized loans, the tax income bracket effect, and the Tanzi-Olivera effect on taxes and governmental revenues. This paper aims to examine a different channel that stresses the role of capital markets and the portfolio composition of financial wealth between money and equity. It is straightforward to argue that changes in the size and composition of wealth are associated with the domestic rate of inflation of an economy. Given that households from lower income groups do not have access to stock markets, it is only the higher income group that is able to protect itself against inflation by shifting its portfolio from money to indexed assets. This reasoning may be justified on the grounds that a minimum amount of entrance costs is generally required to participate in the stock markets. Many younger and poorer households do not hold equities at all. ${ }^{1}$ This fact may be explained if there is a fixed cost of participating in the equity market.

In order to study the effects of inflation on the distribution of wealth, we analyze the households' optimal portfolio allocation over the life cycle in an economy with fixed stock market participation costs. ${ }^{2}$ Contrary to studies that examine the popular redistributional wealth effect from (net) creditors to debtors, which is based on unanticipated inflation and average income, we explicitly investigate a permanent, anticipated change of the inflation rate. A further preconception of our analysis is that "any theory of equality must account for the dynamic features of earnings, income, and wealth distributions, i.e., the mobility of individual (heterogeneous) households up and down the economic scale," (cf. DíazGiménez et al., 1997, p. 10). For this reason, we introduce (stochastic) heterogenous productivity into our model so that our model is able to match both the Gini coefficient of US labor income and the Gini coefficient of US wealth very closely. As our main result from our computational analysis, we demonstrate that higher inflation increases wealth

\footnotetext{
${ }^{1}$ Romer and Romer (1998) note that for US households from the quintile reporting the lowest total income only about one fifth holds a positive amount of financial assets, including non-public stocks (figure based on data from the Federal Reserve's 1995 Survey of Consumer Finances, henceforth SCF).

${ }^{2}$ One of the few papers known to us that studies the inflation effect on wealth inequality is Bhattacharya (2001). The focus of his paper, however, is on the modelling of agency costs.
} 
inequality.

As regards empirical studies, evidence of the relationship between inflation and inequality for the US is quite ambiguous, sometimes even statistically insignificant. A comprehensive survey of the recent literature is given in Galli and van der Hoeven (2001). Accordingly, the vast majority of studies finds a significant progressive effect of inflation on the US income distribution, though mostly small in quantitative terms. About half of the studies, however, does not find a statistically significant effect once additional control variables are considered. For example, Romer and Romer (1998) find statistically insignificant effects of inflation for the US Gini coefficient as well as for the poverty rate as dependent variables in their regressions, in case of controlling for unemployment. However, it should be noted that the focus of this literature is on the US income distribution and therefore abstracts from financial wealth. For the US, wealth is positively correlated with earnings and income, but not strongly (see Díaz-Giménez et al., 1997). All the more, the quantitative, numerical exercise of the present paper aims to shed some light on the relationship between inflation and wealth distribution for the US, in order to fill this gap in the literature.

In addition, a second related problem is studied in this paper. In previous work, Imrohoroğlu (1992) finds a significant welfare effect of inflation. In particular, she demonstrates with the help of numerical computations that an increase of annual inflation from $0 \%$ to $10 \%$ results in welfare losses equivalent to approximately one percent of GNP. Her model is similar to ours, except that we study two assets, both money and equity, while she only considers money. ${ }^{3}$ In this paper, we show that welfare losses are substantially smaller (by a factor of 100) if agents can also accumulate savings in the form of equity.

The remainder of the paper is structured as follows. Section 2 introduces the overlappinggenerations model with two assets, money and equity. The model is calibrated with regard to the characteristics of the US economy in section 3. Our numerical results are presented in section 4 . Section 5 concludes.

\footnotetext{
${ }^{3}$ Furthermore, she only considers the state of employment and unemployment, while we replicate the empirical labor income distribution more closely as we allow for multiple productivity types.
} 


\section{The model}

We study a general equilibrium overlapping generations model with endogenous equity and money distribution. Four sectors can be depicted: households, production, the government, and the central bank. Household maximize discounted life-time utility. Agents can save either with money or with capital. Individuals are heterogeneous with regard to their productivity and cannot insure against idiosyncratic income risk. Firms maximize profits. Output is produced with the help of labor and capital. The government provides unfunded public pensions which are financed by a tax on wage income. The money growth rate is set by the central bank and seignorage is redistributed lump-sum to the households.

\section{$2.1 \quad$ Households}

Every year, a generation of equal measure is born. As we only study steady-state behavior, we concentrate on the behavior of an individual born in period 0 . Their first period of life is period 1. A subscript $j$ of a variable denotes the age of the generation. The total measure of all households is normalized to one.

Households life a maximum of $T+T^{R}$ years. Lifetime is stochastic and agents face a probability $s_{j}$ of surviving up to age $j$ conditional on surviving up to age $j-1$. During their first $T$ years, agents supply labor $l$ elastically. After $T$ years, retirement is mandatory. Agents maximize life-time utility:

$$
E_{0}\left[\sum_{j=1}^{T+T^{R}} \beta^{j-1}\left(\Pi_{i=1}^{j} s_{i}\right) u\left(c_{j}, m_{j}, 1-l_{j}\right),\right]
$$

where $\beta, c_{j}$, and $m_{j}$ denote the discount factor, consumption at age $j$, and real money balances at age $j$, respectively. The instantaneous utility function $u(c, m, 1-l)$ is the CRRA (constant relative-risk aversion) function:

$$
u(c, m, 1-l)= \begin{cases}\gamma \ln c+(1-\gamma) \ln m+B \ln (1-l) & \text { if } \sigma=1 \\ \frac{\left(c^{\gamma} m^{1-\gamma}\right)^{1-\sigma}}{1-\sigma}+B \ln (1-l) & \text { if } \sigma \neq 1\end{cases}
$$

where $\sigma>0$ denotes the coefficient of relative risk aversion. 
Workers are heterogeneous with regard to their labor earnings per working hour. The worker's labor productivity $e(z, j)$ is stochastic and depends on individual age $j$ and an idiosyncratic labor productivity shock $z$.

Furthermore, agents are born without wealth, $a_{1}=0$, and cannot borrow, $a_{j} \geq 0$ for all $j$. Wealth $a$ is composed of real money $m$ and capital $k$. Capital or, equally, equity $k$ earns a real interest rate $r$, but it is costly to enter the stock market. Following Campbell et al. (2001), we assume that once the fixed cost $F$ has been paid, there are no additional costs of adjusting the capital stock $k$. We further assume a short-sale constraint $k \geq 0$. Parents do not leave altruistic bequests to their children. All accidental bequests are confiscated by the state.

Agents receive income from capital $k_{j}$ and labor $l_{j}$. The budget constraint of the working agent at age $j=1, \ldots, T$ is given by

$$
a_{j+1}=k_{j+1}+m_{j+1}=(1+r) k_{j}+\frac{m_{j}}{1+\pi}+\left(f_{j+1}-f_{j}\right) F+(1-\tau) w e(z, t) l_{j}+t r-c_{j}
$$

where $w$ and $\pi_{t}=\frac{P_{t}-P_{t-1}}{P_{t-1}}$ denote the wage rate per efficiency unit labor and the inflation rate, respectively. $P_{t}$ is the price level in period $t$. In steady state, the wage rate $w$, the interest rate $r$, and the inflation rate $\pi$ are constant so that we omit the time index $t$. Wage income is taxed at rate $\tau$. In addition, the households receive transfers $t r$ from the central bank. $f_{j}$ denotes a binary variable that equals zero until the investor pays the fixed cost of entering the stock market and equals one thereafter.

During retirement, agents receive public pensions pen irrespective of their employment history and the budget constraint of the retired agent at age $j=T+1, \ldots, T+T^{R}$ is given by

$$
a_{j+1}=k_{j+1}+m_{j+1}=(1+r) k_{j}+\frac{m_{j}}{1+\pi}+\left(f_{j+1}-f_{j}\right) F+p e n+t r-c_{j} .
$$

\subsection{Production}

Firms are of measure one and produce output with effective labor $N$ and capital $K$. Let $l(k, m, z, f, j)$ and $\phi(k, m, z, f, j)$ denote the labor supply and the measure of the j-year 
old agent with wealth $a=k+m$, previous equity holdings indicator $f \in\{0,1\}$, and idiosyncratic productivity $z$. Effective labor $N$ is given by:

$$
N=\sum_{j=1}^{T} \sum_{f=0,1} \int_{k} \int_{m} \int_{z} l(k, m, z, f, j) e(z, j) \phi(k, m, z, f, j) d z d m d k
$$

Effective labor $N$ is paid the wage $w$. Capital $K$ is hired at rate $r$ and depreciates at rate $\delta$. Production $Y$ is characterized by constant returns to scale and assumed to be Cobb-Douglas:

$$
Y=F(K, N)=K^{\alpha} N^{1-\alpha}
$$

In a factor market equilibrium, factors are rewarded with their marginal product:

$$
\begin{aligned}
& w=(1-\alpha) K^{\alpha} N^{-\alpha}, \\
& r=\alpha K^{\alpha-1} N^{1-\alpha}-\delta
\end{aligned}
$$

\subsection{Government}

The government uses the revenues from taxing labor, $\tau w N$, and from aggregate accidental bequests $B e q$ in order to finance its expenditures on aggregate social security Pen:

$$
\tau w N+B e q=\text { Pen } .
$$

\subsection{Monetary Authority}

Nominal money grows at the exogenous rate $\theta$ :

$$
\frac{M_{t}-M_{t-1}}{M_{t-1}}=\theta
$$

The seignorage is transferred lump-sum to the households:

$$
t r_{t}=\frac{M_{t}-M_{t-1}}{P_{t}}
$$




\subsection{Stationary Equilibrium}

The concept of equilibrium applied in this paper uses a recursive representation of the consumer's problem following Stokey et al. (1989). Let $V_{j}\left(k_{j}, m_{j}, z_{j}, f_{j}\right)$ be the value of the objective function of the $j$-year old agent with equity $k_{j}$, real money $m_{j}$, idiosyncratic productivity level $z_{j}$, and either prior stock market participant $f_{j}=1$ or not $f_{j}=0$. $V_{j}\left(k_{j}, m_{j}, z_{j}, f_{j}\right)$ is defined as the solution to the dynamic program:

$V_{j}\left(k_{j}, m_{j}, z_{j}, f_{j}\right)=\max _{k_{j+1}, m_{j+1}, f_{j+1}, c_{j}, l_{j}}\left\{u\left(c_{j}, m_{j}, 1-l_{j}\right)+\beta s_{j+1} E\left[V_{j+1}\left(k_{j+1}, m_{j+1}, z_{j+1}, f_{j+1}\right)\right]\right\}$

subject to (3) or (4) and $k, m \geq 0$. Optimal decision rules at age $j$ are a function of $k_{j}, m_{j}$, $z_{j}$, and $f_{j}$, i.e. consumption $c_{j}(k, m, z, f)$, labor supply $l_{j}(k, m, z, f)$, next-period capital stock $k_{j+1}(k, m, z, f)$, next-period real money balances $m_{j+1}(k, m, z, f)$, and next-period stock market participation $f_{j+1}(k, m, z, f)$.

We will consider a stationary equilibrium where factor prices and aggregate capital and labor are constant and the distribution of wealth is stationary.

\section{Definition}

A stationary equilibrium for a given government policy with pension system pen and central bank policy $\theta$ is a collection of value functions $V_{j}(k, m, z, f)$, individual policy rules $c_{j}(k, m, z, f), l_{j}(k, m, z, f), k_{j+1}(k, m, z, f), m_{j+1}(k, m, z, f)$, and $f_{j+1}(k, m, z, f)$, relative prices of labor and capital $\{w, r\}$, and distributions $\left(\phi_{1} \equiv \phi(., ., ., ., 1), \ldots, \phi_{T+T^{R}}\right)$, such that:

1. Individual and aggregate behavior are consistent:

$$
\begin{aligned}
K & =\sum_{j=1}^{T+T^{R}} \sum_{f_{j}=0,1} \int_{k} \int_{m} \int_{z} k \phi(k, m, z, f, j) d z d m d k \\
C & =\sum_{j=1}^{T+T^{R}} \sum_{f_{j}=0,1} \int_{k} \int_{m} \int_{z} c_{j}(k, m, z, f) \phi(k, m, z, f, j) d z d m d k \\
B e q & =\sum_{j=1}^{T+T^{R}} \sum_{f_{j}=0,1} \int_{k} \int_{m} \int_{z}\left(1-s_{j+1}\right) a_{j+1}(k, m, z, f) \phi(k, m, z, f, j) d z d m d k
\end{aligned}
$$




$$
\begin{aligned}
\text { Pen } & =\sum_{j=T+1}^{T+T^{R}} \sum_{f_{j}=0,1} \int_{k} \int_{m} \int_{z} \text { pen } \phi(k, m, z, f, j) d z d m d k, \\
\frac{M}{P} & =\sum_{j=1}^{T+T^{R}} \sum_{f_{j}=0,1} \int_{k} \int_{m} \int_{z} m \phi(k, m, z, f, j) d z d m d k,
\end{aligned}
$$

where $a_{j+1}(k, m, z, f) \equiv k_{j+1}(k, m, z, f)+m_{j+1}(k, m, z, f)$ and aggregate effective labor $N$ is given by (5).

2. Relative prices $\{w, r\}$ solve the firm's optimization problem by satisfying (7) and (8).

3. Given relative prices $\{w, r\}$, the government policy pen, the individual policy rules $c_{j}(),. k_{j+1}(),. m_{j+1}(),. l_{j}($.$) , and f_{j+1}($.$) solve the consumer's dynamic program (12).$

4. The government budget (9) is balanced.

5. Money grows at the exogenous rate $\theta$ and the seignorage (11) is transferred lump-sum to the households.

6. The goods market clears:

$$
K^{\alpha} N^{1-\alpha}=C+\delta K+\sum_{j=1}^{T+T^{R}} \int_{k} \int_{m} \int_{z} F \cdot f_{j+1}(k, m, z, 0) \phi(k, m, z, f, j) d z d m d k
$$

In particular, stock market participation fees are a social cost.

\section{Calibration}

Periods correspond to years. We assume that agents are born at real lifetime age 20 which corresponds to $j=1$. Agents work $T=40$ years corresponding to a real lifetime age of 60. They life a maximum life of 60 years $\left(T^{R}=20\right)$ so that agents do not become older than real lifetime age 80 . The sequence of conditional survival probabilities $\left\{s_{j}\right\}_{j=1}^{59}$ is set equal to the Social Security Administration's survival probabilities for men aged 20-78 for the year $1994 .^{4}$ The survival probabilities decrease with age, and $s_{60}$ is set equal to zero.

In our benchmark case, we choose the case of log-linear preferences $\sigma=1$. For this calibration, money is superneutral in the representative-agent, infinite-lifetime Sidrauski

\footnotetext{
${ }^{4}$ We thank Mark Huggett and Gustavo Ventura for providing us with the data.
} 
Table 1: Calibration of parameter values for the US economy

\begin{tabular}{lll} 
Description & \multicolumn{1}{c}{ Function } & \multicolumn{1}{c}{ Parameter } \\
\hline utility function & $U=\gamma \ln c+(1-\gamma) \ln m+B \ln (1-l)$ & $\gamma=0.984, B=1.95$ \\
discount factor & $\beta$ & $\beta=0.96$ \\
production function & $Y=K^{\alpha} N^{1-\alpha}$ & $\alpha=0.36$ \\
depreciation & $\delta$ & $\delta=0.08$ \\
stock market participation & $F$ & $F=0$ \\
fee & & \\
money growth rate & $\theta$ & $\theta=0.05$ \\
pension replacement rate & & $\frac{p e n}{(1-\tau) w l}=0.50$ \\
labor endowment process & $z_{t}=\rho z_{t-1}+\epsilon_{t}, \epsilon_{t} \sim N\left(0, \sigma_{\epsilon}\right)$ & $\rho=0.96, \sigma_{\epsilon}=0.045$ \\
& $\ln e(z, 1) \sim N\left(\bar{y}_{1}, \sigma_{y_{1}}\right)$ & $\sigma_{y 1}=0.38$
\end{tabular}

model, and we expect the effect of inflation on wealth distribution to be of small magnitude in our OLG model with heterogeneous agents. Furthermore, there is no stock market participation fee in the benchmark, i.e. $F=0$. The model parameters are presented in table 1.

The calibration of the parameters $\alpha, \delta$, pen, and $\theta$ and the Markov process $e(z, j)$ is chosen in accordance with existing general equilibrium studies: Following Prescott (1986), the capital income share $\alpha$ is set equal to 0.36 . The annual rate of depreciation is set equal to $\delta=0.08$. Pensions are distributed lump-sum to the retired agents. The replacement ratio of pensions to net average earnings amounts to $50 \%$. The annual money growth rate $\theta$ is set equal to $5 \%$ in our benchmark case.

The labor endowment process is given by $e(z, j)=e^{z_{j}+\bar{y}_{j}}$, where $\bar{y}_{j}$ is the mean lognormal income of the $j$-year old. The mean efficiency index $\bar{y}_{j}$ of the j-year-old worker is taken from Hansen (1993) and interpolated to in-between years. As a consequence, the model is able to replicate the cross-section age distribution of earnings of the US economy. Following 
İmrohoroğlu et al. (1998), we normalize the average efficiency index to one. The ageproductivity profile is hump-shaped and earnings peak at age 50 .

The idiosyncratic productivity shock $z_{j}$ follows a Markov process:

$$
z_{j}=\rho z_{j-1}+\epsilon_{j}
$$

where $\epsilon_{j} \sim N\left(0, \sigma_{\epsilon}\right)$. Huggett (1996) uses $\rho=0.96$ and $\sigma_{\epsilon}=0.045$. Furthermore, we follow Huggett and choose a lognormal distribution of earnings for the 20-year old with $\sigma_{y_{1}}=$ 0.38 and mean $\overline{y_{1}}$. As the $\log$ endowment of the initial generation of agents is normally distributed, the log efficiency of subsequent agents will continue to be normally distributed. This is a useful property of the earnings process, which has often been described as log normally in the literature.

The remaining three parameters $\beta, B$, and $\gamma$ from the utility function are chosen to match the following characteristics of the US economy as closely as possible: i) the capital-output ratio $K / Y$ amounts to 3.0 as found by Auerbach and Kotlikoff (1995), ii) the average labor supply of the working households equals to approximately one third of available time, and iii) the average velocity of money $P Y / M$ corresponds to the annual velocity of M1 during 1960-2001, which is equal to 5.18. Our calibration $\beta=0.96, B=1.95$, and $\gamma=0.984$ implies a capital-output ratio equal to 2.96 , an average labor supply $\bar{l}=0.326$, and an annual velocity of money equal to 5.23. In our sensitivity analysis, we also study the case $\sigma=2$. In order to replicate the empirical findings (i)-(iii) from above, we need to choose $\beta=0.955, B=6.10$, and $\gamma=0.988$. For this calibration, the capital-output ratio, the velocity of money, and the average labor supply amount to $K / Y=3.02, P Y / M=5.05$, and $\bar{l}=0.329$, respectively.

\section{Results}

In this section, we study the effects of a change of the money growth rate $\theta$ or, equally, the inflation rate $\pi$ on the accumulation and distribution of wealth. First, we report findings for the benchmark case as described by the parameterization in table 1. Second, we analyze the effects of a stock market participation fee. Finally, we consider the sensitivity of our results with regard to the assumption of log-linear utility and the replacement ratio of pensions. 
Table 2: Inflation rate $\pi$, savings, and distribution

\begin{tabular}{cc|ccccccc}
\hline & & & & & & & & \\
$\pi$ & $F$ & $K$ & $M / P$ & $Y$ & Gini $_{k}$ & Gini $_{a}$ & $S M P$ & $\Delta_{c}$ \\
\hline & & & & & & & & \\
$5 \%$ & 0 & 1.842 & 0.119 & 0.622 & 0.720 & 0.701 & $53.6 \%$ & $0 \%$ \\
$20 \%$ & 0 & 1.814 & 0.0529 & 0.619 & 0.737 & 0.729 & $52.5 \%$ & $-0.0128 \%$ \\
\hline $5 \%$ & 0.0622 & 1.823 & 0.116 & 0.622 & 0.732 & 0.714 & $48.6 \%$ & $-0.0150 \%$ \\
$20 \%$ & 0.0616 & 1.807 & 0.0528 & 0.616 & 0.740 & 0.732 & $46.1 \%$ & $-0.0167 \%$ \\
\hline
\end{tabular}

\subsection{The benchmark case}

In our benchmark equilibrium, the annual inflation rate is equal to $5 \%$ and there are no fixed stock market participation fees, $F=0$. The endogenous equilibrium values of the benchmark are reported in the first row of table 2 . The aggregate capital stock $K$ amounts to 1.84, while effective labor $N$ and the average supply $\bar{l}$ (not reported) are equal to 0.340 and 0.326 , respectively, implying a real interest rate $r$ of $4.11 \%$.

In our model, the productivity process is taken as exogenous. As, however, the agent optimizes his lifetime utility by choice of his labor supply, both the distribution of labor income, $(1-\tau) w e(z, t) l$, and the distribution of wealth, equity $k$ plus real money $m$, are endogenous. The Gini coefficient of the labor income distribution amounts to 0.481 and is close to the values observed empirically: Díaz-Giménez et al. (1997) find a value of 0.51 for households aged 36-50, while Henle and Ryscavage (1980) estimate an average US earnings Gini coefficient for men of 0.42 in the period $1958-77 .^{5}$

Empirically, wealth is distributed much more unequally than income. Greenwood (1983), Wolff (1987), Kessler and Wolff (1992), and Díaz-Giménez et al. (1997) estimate Gini coefficients of the wealth distribution for the US economy in the range of 0.72 (single, without dependents, female household head) to 0.81 (nonworking household head). Our model is able to replicate these findings. In particular, the Gini coefficient of wealth is equal to Gini $_{a}=0.701$, while the Gini coefficient of equity is even higher and amounts to Gini $_{k}=$ 0.720. The Lorenz curve for the benchmark case of our model and for the US economy

\footnotetext{
${ }^{5}$ Income transfers are excluded in the respective definition of earnings.
} 
are displayed in figure $1 .^{6}$ The empirical distribution that is presented by the broken line displays a higher concentration of wealth among the very wealth-rich agents than the model distribution, while the number of households with no wealth is lower in the US economy than in our model. In particular, only $53.6 \%$ (=SMP) of all households participate in the stock market in our model. ${ }^{7}$ The main reason why our model underestimates the high concentration of wealth among the top $5 \%$ of the wealthiest households is the negligence of i) self-employment and ii) bequests. ${ }^{8}$

Figure 1: Lorenz curve of model and US wealth $a$

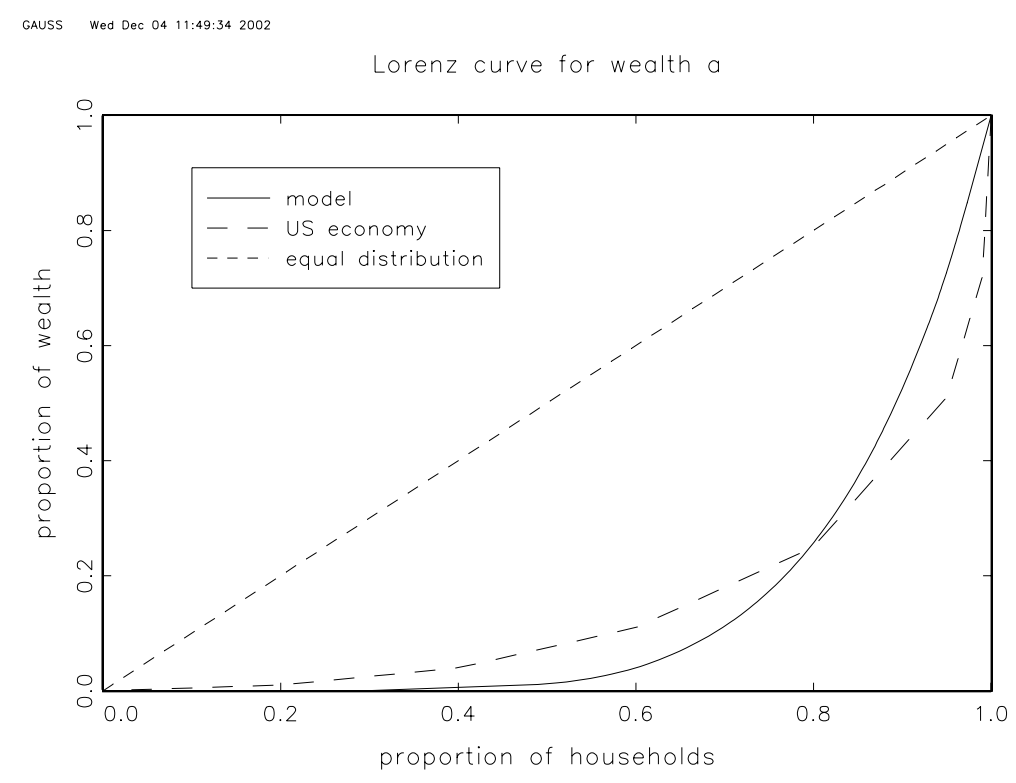

In the Sidrauski model with infinite lifetime and a representative household, money is superneutral for our log-linear functional form of the utility function with $\sigma=1$. In

\footnotetext{
${ }^{6}$ The data for the empirical distribution of wealth are taken from Wolff (1987).

${ }^{7}$ From 1983-98, between 86 and $90 \%$ of all US households held interest bearing accounts. In 1998, 38\% of households held (tax-deferred) equity. Figures are based on data from SCF (see Poterba and Samwick, 2001). One possible reason that, in our model, the percentage of the households that own stocks is higher than observed empirically is the negligence of investment in housing. In particular, a leveraged position in residential estate may keep younger and poorer households from investing in the stock market (see Cocco, 2001).

${ }^{8}$ For a review of recent studies that explain the wealth distribution in general equilibrium models with, among others, the help of idiosyncratic shocks to labor earnings, business ownership, and changes in health and marital status; see Quadrini and Ríos-Rull (1997). Heer (2001) studies the effects of bequests on the distribution of wealth.
} 
our model, superneutrality does no longer hold. In particular, we assume that seignorage is redistributed lump-sum. As income-rich agents have a higher propensity to save out of income and also hold more money balances than income-poor agents, a higher inflation tax with a corresponding higher seignorage redistributes income to the income-poor agents. As a consequence, not only total money savings $M / P$ but also aggregate equity savings $K$ decline. An increase of the inflation rate $\pi$ from $5 \%$ to $20 \%$ decreases aggregate wealth from $K=1.842$ to 1.814 . The distribution of wealth $a$ and capital $k$ becomes more unequal (compare the second row of table 2), but the quantitative effect is of small magnitude. As the lump-sum component of the income is increased, precautionary savings among the wealth-poor and income-poor households decline by a higher percentage than savings among the rich households.

We also analyze steady-state welfare for the different monetary policy regimes $\theta$. In order to compare the welfare effects, we compute the expected discounted lifetime utility of the newborn generation for the different values of $\theta$. To quantitatively assess the effects, we take the benchmark equilibrium as presented in table 1 as our reference economy. The change in welfare $\Delta_{c}$ is computed as the compensation in consumption (relative to the reference economy) required in order to make the average newborn indifferent between the reference economy and the alternative policy regime. As presented in table 2, the steady-state welfare effect of an increase in the anticipated rate of inflation is negligible and amounts to a loss of $0.0128 \%$ of total consumption.

\subsection{Stock market participation fees}

Transaction costs of stock markets have been prominently applied in the explanation of the equity premium puzzle, e.g. by He and Modest (1995), or in the study of the effects of pension reform on retirement wealth, e.g. by Campbell et al. (2001). The motivation to introduce fixed stock market fees into our model is the idea that the adverse effects of inflation on poor households' wealth and on the wealth distribution are exacerbated. Due to the high costs of entering the stock market, most income-poor households hold wealth only in the form of money. As inflation increases, these agents are affected more severely by the inflation tax and might reduce their precautionary money savings. In addition, it is not clear a priori if higher inflation also results in higher stock market participation. On 
the one hand, the increase of the inflation tax makes capital a more attractive investment than money. On the other hand, agents may have accumulated small wealth in the form of money if their productivity $z$ is low and, in case of a transistory positive productivity shock, they may not have accumulated enough wealth to pay the fixed stock market costs. Our results for the model with transaction costs are presented in the third and fourth row of table 2. Like Campbell et al. (2001), we choose a fixed stock market fee $F$ equal to $10 \%$ of average annual income as the upper bound. As a consequence, the stock market participation rate drops by five percentage points in comparison to the benchmark case, from $53.6 \%$ to $48.6 \%$. The capital stock $K$ only declines by a small fraction from 1.842 to 1.823 as the income-rich agents continue to hold wealth in the form of equity. Furthermore, the wealth inequality increases slightly because the very poor cannot afford to participate in the stock market.

As in the case without transaction costs, $F=0$, an increase of inflation from $5 \%$ to $20 \%$ results in only quantitatively negligible welfare losses equivalent to $0.0017 \%$ of total consumption. Our quantitative welfare effects of inflation are in sharp contrast with the findings of İmrorohoğlu (1992). She finds that reducing steady-state inflation from $10 \%$ to $0 \%$ results in a considerable welfare gain equivalent to an increase of income equal to $1.07 \%$. Similar to the model in the present paper, she considers a heterogeneous-agent economy with imperfect insurance. The distribution of wealth is endogenous and agents are also subject to a productivity shock that can only take the value zero (unemployment) or one (employment). Different from our economy, however, agents can accumulate savings only in the form of non-interest bearing money. In our model, some households enter the stock market and also use equity in order to smooth consumption intertemporally, while the other agents do not pay the stock market participation fee so that they accumulate savings, if any, in the form of money. For this, as we believe, more realistic description of the savings behavior of individual agents, we find that welfare losses from higher anticipated inflation are negligible.

\subsection{Sensitivity analysis}

In this subsection, we examine the sensitivity of our results with regard to the choice of the utility parameter and the pension replacement ratio. First, we will analyze the case $\sigma=2$. 
Table 3: Inflation rate $\pi$, savings, and distribution for $\sigma=2$

\begin{tabular}{cc|ccccccc}
\hline & & & & & & & & \\
$\pi$ & $F$ & $K$ & $M / P$ & $Y$ & Gini $_{k}$ & Gini $_{a}$ & SMP & $\Delta_{c}$ \\
\hline $5 \%$ & 0 & 1.507 & 0.0980 & 0.4950 & 0.716 & 0.697 & $54.1 \%$ & $0 \%$ \\
$20 \%$ & 0 & 1.496 & 0.0463 & 0.4933 & 0.731 & 0.721 & $48.5 \%$ & $-0.0058 \%$ \\
\hline $5 \%$ & 0.0494 & 1.465 & 0.0952 & 0.4944 & 0.734 & 0.715 & $48.5 \%$ & $-0.0249 \%$ \\
$20 \%$ & 0.0493 & 1.457 & 0.0468 & 0.4928 & 0.742 & 0.731 & $46.7 \%$ & $-0.0342 \%$ \\
\hline
\end{tabular}

For this calibration, money is no longer superneutral even in the model with homogeneous agents. ${ }^{9}$ However, as in the representative-agent case, the quantitative effects of a change in the inflation rate are demonstrated to be of small magnitude. Second, we study a change in the replacement ratio of public pensions from $50 \%$ to $30 \%$. In this case, workers increase their savings and more income-poor agents participate in the stock market. Again, fixed stock market participation fees are found to be of minor importance for the inflation effects.

\section{Utility function}

Table 3 presents our numerical results for a change in the utility parameter $\sigma$. For higher risk aversion $\sigma=2$, agents increase their precautionary savings and their labor supply. For this reason, we recalibrated our model in order to have the same average labor supply and the same capital-output ratio as in our benchmark case. In particular, the relative weight of the utility from leisure $B$ has been increased and the discount factor $\beta$ has been decreased, as has been already pointed out in section 3. With higher risk aversion, the labor supply of the low-income group increases relative to the one of the high-income group resulting in a drop of the labor income heterogeneity. The Gini coefficient of labor income decreases from 0.481 in the benchmark case with $\sigma=1$ to 0.374 in the case with $\sigma=2$. Notice that this strong decrease in income inequality is not accompanied by a proportional change in the wealth inequality, which, according to the Gini coefficient of wealth $a$, only drops from 0.701 to 0.697 (compare table 2 and table 3 for the two cases $\sigma=1$ and $\sigma=2$ ).

All our numerical results are analogous to those in the case of $\sigma=1$. In particular, an

\footnotetext{
${ }^{9}$ See, e.g., Walsh (1998), Ch. 2.3.
} 
Table 4: Inflation rate $\pi$, savings, and distribution for $r e p=0.3$

\begin{tabular}{cc|ccccccc}
\hline & & & & & & & & \\
$\pi$ & $F$ & $K$ & $M / P$ & $Y$ & Gini $_{k}$ & Gini $_{a}$ & SMP & $\Delta_{c}$ \\
\hline & & & & & & & & \\
$5 \%$ & 0 & 1.954 & 0.1232 & 0.6464 & 0.705 & 0.688 & $54.8 \%$ & $0 \%$ \\
$20 \%$ & 0 & 1.943 & 0.0572 & 0.6432 & 0.720 & 0.711 & $50.7 \%$ & $-0.0072 \%$ \\
\hline $5 \%$ & 0.0643 & 1.942 & 0.1211 & 0.6434 & 0.715 & 0.697 & $51.5 \%$ & $-0.0086 \%$ \\
$20 \%$ & 0.0641 & 1.930 & 0.0585 & 0.6414 & 0.721 & 0.714 & $49.9 \%$ & $-0.0108 \%$ \\
\hline
\end{tabular}

increase of inflation by 15 percentage points from $5 \%$ to $20 \%$ results in i) a decrease of aggregate capital $K$ by less than one percent, ii) a small increase of wealth inequality as measured by the Gini coefficient, and iii) a welfare loss in the magnitude of approximately $0.01 \%$ of total consumption. Again, the consideration of fixed stock market participation fees does not alter our qualitative and quantitative results. Compared to the case with no stock market entry $\operatorname{costs} F=0$, savings $K$ are smaller and wealth inequality is higher.

\section{Pensions}

Due to the high lump-sum pensions, low-income households do not save for retirement, neither in the form of money nor in the form of equity. Reducing the pension replacement ratio from $50 \%$ to $30 \%$ results in higher savings. In the benchmark case with $\sigma=1$, aggregate equity increases from $K=1.842$ to $K=1.991$. The change of the other equilibrium values is also presented in table 4 . Notice that the effects of higher inflation on aggregate capital $K$, wealth inequality, and welfare are insensitive with regard to the choice of the pension replacement ratio. Following a rise of the inflation $\pi, K$ decreases, $\Delta_{c}$ is negative, but small, and the Gini coefficients of capital and wealth increase.

\section{Conclusion}

Empirical results on the effects of inflation on the distribution of wealth are scarce. While there is empirical support to the hypothesis that anticipated inflation increases income inequality, no related evidence is available for the effects of inflation on wealth inequality. 
This paper offers a contribution to fill this gap in the empirical literature by analyzing a computable general equilibrium model of the wealth distribution. As our main result, we find that higher inflation increases wealth inequality; however, quantitative effects are small even in the presence of substantial stock market participation fees.

In this model, we also study the welfare costs of inflation. In our economy, agents face idiosyncratic risk and try to smooth consumption intertemporally as in İmrohoroğlu (1992). Different from her, agents cannot only accumulate savings in the form of money but also in the form of equity. From her results, A. Imrohoroğlu concludes that the area under the empirical money demand curve is a poor measure of the welfare costs of inflation. In her model, welfare costs are higher by the factor 3-4. We come to the opposite conclusion. In our study, the area under the empirical money demand curve overestimates the true costs of inflation by a factor of approximately 25-40, once we allow for general equilibrium effects, heterogeneous agents, and consumption smoothing with the help of equity. 


\section{Appendix: Computation}

The solution algorithm is described by the following steps:

1. Parameterize the model.

2. Make initial guesses of the aggregate capital stock $K$, aggregate effective labor $N$, aggregate real money $M / P$, and the wage income tax rate $\tau$.

3. Compute the values of $w$ and $r$ that solve the firm's Euler equations. Compute the pension pen so that the replacement rate of average pensions is equal to the empirical value. Compute the transfers $t r$.

4. Compute the household's decision functions by backwards iteration.

5. Compute the steady-state distribution of the state variable $\{k, m, f, z, t\}$ by forward induction.

6. Compute the aggregate capital stock $K$, aggregate real money balances $M / P$, and aggregate accidental bequests $B e q$ and pensions $P e n$. Update $K, M / P, N$, and $\tau$ and return to step 2 until convergence.

We discretize the state space $(k, m, z, f)$ using an equispaced grid over the capital stock $k$, the money balances $m$, and the individual productivity $z$. The upper grid points $k_{\max }=$ 10.0 and $m_{\max }=0.3$ are found to be non-binding. For the productivity $z$, the grid ranges from $-2 \sigma_{y_{1}}$ to $2 \sigma_{y_{1}}$. The probability of having productivity shock $z_{1}$ in the first period of life is computed by integrating the area under the normal distribution. The transition probabilities are computed using the method of Tauchen (1986). As a consequence, the efficiency index $e(z, j)$ follows a finite Markov chain.

In step 4, a finite-time dynamic programming problem is to be solved. We use standard value function iteration over the state space grid $\{k, m, z, f\}$ to find the optimal nextperiod values $k^{\prime}, m^{\prime}$, and $f^{\prime}$. For the working agent, we also have to compute the optimal labor supply from his budget constraint and his first-order condition:

$$
u_{1-l}(c, m, 1-l)=u_{c}(c, m, 1-l)(1-\tau) e(z, j) w .
$$


As the household is born without any assets, his first-period wealth and his real money balances are zero. As a consequence, the value function would take the value $-\infty$ as $m_{1}=0$. For computational purposes, therefore, we slightly change the utility function and introduce a small constant $\psi$ into $(2), \tilde{u}=u(c, m+\psi, 1-l)$. 


\section{References}

Auerbach, A. and L. Kotlikoff, 1995, Macroeconomics: An Integrated Approach, SouthWestern College Publishing, Cincinnati, OH.

Bhattarchaya, J., 2001, Inflation, Real Activity, and Income Distribution, Iowa State University, working paper.

Campbell, J., J. Cocco, F. Gomes, and P. Maenhout, 2001, Investing Retirement Wealth: A Life-Cycle Model, in: J.Y. Campbell and M. Feldstein, eds., Risk Aspects of Investment-Based Social-Security Reform, Chicago University Press, Chicago, 43973.

Cocco, J.F., 2001, Portfolio Theory in the Presence of Housing, working paper, London Business School.

Díaz-Giménez, J., V. Quadrini, and J.V. Ríos-Rull, 1997, Dimensions of Inequality: Facts on the U.S. Distributions of Earnings, Income, and Wealth, Federal Reserve Bank of Minneapolis Quarterly Review 21, 3-21.

Galli, R. and R. van der Hoeven, 2001, Is Inflation Bad for Income Inequality: The Importance of the Initial Rate of Inflation, International Labor Organization Employment Paper 2001/29.

Greenwood, D., 1983, An Estimation of US Family Wealth and Its Distribution from Microdata, 1973, Review of Income and Wealth, vol. 24, 23-44.

Hansen, G., 1993, The cyclical and secular behavior of the labor input: comparing efficiency units and hours worked, Journal of Applied Econometrics 8, 71-80.

He, H. and D.M. Modest, 1995, Market Frictions and Consumption-Based Asset Pricing, Journal of Political Economy, vol. 103, 94-117.

Heer, B., 2001, Wealth Distribution and Optimal Inheritance Taxation, in Life-cycle Economies with Intergenerational Transfers, Scandinavian Journal of Economics, vol. 103, 445-65.

Henle, P., and P. Ryscavage, 1980, The distribution of earned income among men and women 1958-77, Monthly Labor Review, April, 3-10.

Huggett, M., 1996, Wealth distribution in Life-Cycle Economies, Journal of Monetary Economics, vol. 17, 953-69.

İmrohoroğlu, A., 1992, Welfare Costs of Inflation under Imperfect Insurance, Journal of Economic Dynamics and Control, vol. 16, 79-91. 
İmrohoroğlu, A, İmrohoroğlu, S., and D.H. Joines, 1998, The Effect of Tax-favored Retirement Accounts on Capital Accumulation, American Economic Review, vol. 88, 749-68.

Kessler, D. and E.N. Wolff, 1992, A Comparative Analysis of Household Wealth Patterns in France and the United States, Review of Income and Wealth, vol. 37, 249-66.

Poterba, J.M. and A.A. Samwick, 2002, Taxation and Household Portfolio Composition: U.S. Evidence from the 1980s and 1990s, forthcoming in Journal of Public Economics.

Prescott, E., 1986, Theory Ahead of Business Cycle Measurement, Federal Reserve Bank of Minneapolis Quarterly Review, vol. 10, 9-22.

Quadrini, V. and J.V. Ríos-Rull, 1997, Understanding the US Distribution of Wealth, Federal Reserve Bank of Minneapolis Quarterly Review, vol. 21, 22-36.

Romer, C.D. and D.H. Romer , 1998, Monetary Policy and the Well-Being of the Poor, NBER Working Paper Series, Working Paper 6793.

Stokey, N., J.R. Lucas, and E.C. Prescott, 1989, Recursive methods in economic dynamics, Harvard University Press, Cambridge, Ma.

Tauchen, G., 1986, Finite State Markov-Chain Approximations To Univariate and Vector Autoregressions, Economics Letters, vol. 20, 177-81

Walsh, C.E., 1998, Monetary theory and policy, MIT Press, Cambridge, Ma.

Wolff, E., 1987, Estimate of household wealth inequality in the US, 1962-1983, Review of Income and Wealth, vol. 33, 231-57. 


\section{CESifo Working Paper Series}

(for full list see www.cesifo.de)

769 Rudi Dornbusch, The New International Architecture, September 2002

770 Hans-Werner Sinn, Weber's Law and the Biological Evolution of Risk Preferences: The Selective Dominance of the Logarithmic Utility Function, September 2002

771 Thomas Mayer, The Macroeconomic Loss Function: A Critical Note, September 2002

772 Seppo Honkapohja and Kaushik Mitra, Learning Stability in Economies with Heterogenous Agents, September 2002

773 David Laidler, Inflation Targets Versus International Monetary Integration - A Canadian Perspective, September 2002

774 Morten I. Lau, Panu Poutvaara, and Andreas Wagener, The Dynamic Cost of the Draft, September 2002

775 Steven Brakman, Harry Garretsen, and Charles van Marrewijk, Locational Competition and Agglomeration: The Role of Government Spending, September 2002

776 Anke S. Kessler and Christoph Lülfesmann, The Theory of Human Capital Revisited: On the Interaction of General and Specific Investments, September 2002

777 Kjell Erik Lommerud, Frode Meland and Lars Sørgard, Unionized Oligopoly, Trade Liberalization and Location Choice, September 2002

778 Antonio Merlo and François Ortalo-Magné, Bargaining over Residential Real Estate: Evidence from England, September 2002

$779 \mathrm{Yu}-\mathrm{Fu}$ Chen and Michael Funke, Exchange Rate Uncertainty and Labour Market Adjustment under Fixed and Flexible Exchange Rates, September 2002

780 Michael S. Michael, International Migration, Income Taxes and Transfers: A Welfare Analysis, September 2002

781 Clemens Fuest and Alfons Weichenrieder, Tax Competition and Profit Shifting: On the Relationship between Personal and Corporate Tax Rates, October 2002

782 Jan Bouckaert and Hans Degryse, Softening Competition by Enhancing Entry: An Example from the Banking Industry, October 2002

783 Johann K. Brunner and Susanne Pech, Adverse Selection in the Annuity Market with Sequential and Simultaneous Insurance Demand, October 2002

784 Gregory D. Hess and Eduard Pelz, The Economic Welfare Cost of Conflict: An Empirical Assessment, October 2002 
785 Jan Erik Askildsen, Uwe Jirjahn, and Stephen C. Smith, Works Councils and Environmental Investment: Theory and Evidence from German Panel Data, October 2002

786 Geir H. Bjønnes, Dagfinn Rime, and Haakon O. Aa. Solheim, Volume and Volatility in the FX-Market: Does it matter who you are?, October 2002

787 John Evans and John Fingleton, Entry Regulation and the Influence of an Incumbent Special Interest Group, October 2002

788 Wolfgang Ochel, International Comparisons and Transfer of Labour Market Institutions, October 2002

789 B. Gabriela Mundaca, Moral Hazard Effects of Bailing out under Asymmetric Information, October 2002

790 Gene M. Grossman and Edwin L.-C. Lai, International Protection of Intellectual Property, October 2002

791 John Hassler, José V. Rodriguez Mora, Kjetil Storesletten, and Fabrizio Zilibotti, A Positive Theory of Geographic Mobility and Social Insurance, October 2002

792 Paul De Grauwe and Marianna Grimaldi, The Exchange Rate in a Model with Heterogeneous Agents and Transactions Costs, October 2002

793 Guido Friebel and Mariassunta Giannetti, Fighting for Talent: Risk-shifting, Corporate Volatility, and Organizational Change, October 2002

794 Jan Erik Askildsen, Badi H. Baltagi, and Tor Helge Holmås, Will Increased Wages Reduce Shortage of Nurses? A Panel Data Analysis of Nurses' Labour Supply, October 2002

795 Marko Köthenbürger and Panu Poutvaara, Social Security Reform and Intergenerational Trade: Is there Scope for a Pareto-Improvement?, October 2002

796 Paul De Grauwe and Laura Rinaldi, A Model of the Card Payment System and the Interchange Fee, October 2002

797 Volker Böhm and Tomoo Kikuchi, Dynamics of Endogenous Business Cycles and Exchange Rate Volatility, October 2002

798 Mariam Camarero, Javier Ordóñez, and Cecilio Tamarit, The Euro-Dollar Exchange Rate: Is it Fundamental?, October 2002

799 Misa Tanaka, How Do Bank Capital and Capital Adequacy Regulation Affect the Monetary Transmission Mechanism?, October 2002

800 Jörg Baten and Andrea Wagner, Autarchy, Market Disintegration, and Health: The Mortality and Nutritional Crisis in Nazi Germany, 1933-1937, October 2002 
801 Saku Aura, Uncommitted Couples: Some Efficiency and Policy Implications of Marital Bargaining, October 2002

802 Wolfram F. Richter, Delaying Integration of Immigrant Labor for the Purpose of Taxation, October 2002

803 Gil S. Epstein and Shmuel Nitzan, The Politics of Randomness, October 2002

804 John Hassler and José V. Rodriguez Mora, Should UI Benefits Really Fall over Time?, October 2002

805 Friedrich Breyer and Stefan Felder, The Dead-anyway Effect Revis(it)ed, October 2002

806 Assar Lindbeck and Solveig Wikström, E-exchange and the Boundary between Households and Organizations, November 2002

807 Dieter Bös, Contests Among Bureaucrats, November 2002

808 Steven Brakman, Harry Garretsen, and Marc Schramm, The Strategic Bombing of German Cities during World War II and its Impact on City Growth, November 2002

809 Florian Englmaier and Achim Wambach, Contracts and Inequity Aversion, November 2002

810 Sarbajit Sengupta, Delegating Recruitment under Asymmetric Information, December 2002

811 Rajshri Jayaraman, On the Partial Public Provision of a Private Good, December 2002

812 Stéphanie Stolz, Banking Supervision in Integrated Financial Markets: Implications for the EU, December 2002

813 Christian Keuschnigg, Taxation of a Venture Capitalist with a Portfolio of Firms, December 2002

814 Inés Macho-Stadler and David Pérez-Castrillo, Settlement in Tax Evasion Prosecution, December 2002

815 Rainer Niemann and Dirk Simons, Costs, Benefits, and Tax-induced Distortions of Stock Option Plans, December 2002

816 Jan-Egbert Sturm and Barry Williams, Deregulation, Entry of Foreign Banks and Bank Efficiency in Australia, December 2002

817 V. Anton Muscatelli, Patrizio Tirelli, and Carmine Trecroci, Monetary and Fiscal Policy Interactions over the Cycle: Some Empirical Evidence, December 2002

818 Claude Hillinger, A General Theory of Price and Quantity Aggregation and Welfare Measurement, December 2002 
819 Erkki Koskela and Ronnie Schöb, Optimal Capital Taxation in Economies with Unionised and Competitive Labour Markets, December 2002

820 Sheilagh Ogilvie, Guilds, Efficiency, and Social Capital: Evidence from German ProtoIndustry, December 2002

821 Hans Gersbach and Verena Liessem, Financing Democracy, December 2002

822 Costas Hadjiyiannis, Panos Hatzipanayotou, and Michael S. Michael, Optimal Tax Policies with Private-Public Clean-Up, Cross-Border Pollution and Capital Mobility, December 2002

823 François Ortalo-Magné and Sven Rady, Homeownership: Low Household Mobility, Volatile Housing Prices, High Income Dispersion, December 2002

824 Syed M. Ahsan and Panagiotis Tsigaris, Measuring the Social Discount Rate under Uncertainty: A Methodology and Application, December 2002

825 Kai A. Konrad, Altruism and Envy in Contests: An Evolutionarily Stable Symbiosis, December 2002

826 Robert S. Chirinko and Huntley Schaller, A Revealed Preference Approach to Understanding Corporate Governance Problems: Evidence from Canada, December 2002

827 Geir B. Asheim, Green National Accounting for Welfare and Sustainability: A Taxonomy of Assumptions and Results, December 2002

828 Andrea Gebauer, Chang Woon Nam, and Rüdiger Parsche, Lessons of the 1999 Abolition of Intra-EU Duty Free Sales for Eastern European EU Candidates, December 2002

829 Giacomo Corneo, Work and Television, December 2002

830 Vivek H. Dehejia and Yiagadeesen Samy, Trade and Labour Standards - Theory, New Empirical Evidence, and Policy Implications, December 2002

831 Geir B. Asheim and Wolfgang Buchholz, A General Approach to Welfare Measurement through National Income Accounting, December 2002

832 Aaron Tornell and Frank Westermann, The Credit Channel in Middle Income Countries, January 2002

833 Gebhard Flaig, Time Series Properties of the German Monthly Production Index, January 2002

834 Campbell Leith and Jim Malley, Estimated Open Economy New Keynesian Phillips Curves for the G7, January 2002

835 Burkhard Heer and Bernd Süssmuth, Inflation and Wealth Distribution, January 2002 